\title{
Analisis Vegetasi Beberapa Fragmen Hutan di Kabupaten Timor Tengah Utara
}

\author{
Vegetation Analysis of Forest Fragments in Timor Tengah Utara District
}

\author{
Aloisius Poleng ${ }^{1}$ dan Joko R. Witono ${ }^{2}$ \\ ${ }^{1}$ Jurusan Biologi, Program Pascasarjana FMIPA, Universitas Indonesia, Gedung E FMIPA, Depok 16424 \\ ${ }^{2}$ Pusat Konservasi Tumbuhan-Kebun Raya Bogor, LIPI, Jl. Ir. H. Juanda 13, Bogor 16003. e-mail : \\ inetpc@indo.net.id atau jrwitono@yahoo.com,*Penulis untuk korespondensi
}

\begin{abstract}
The present study aims to describe vegetation composition and structure of fragmented areas in Timor Tengah Utara. The study was carried out in three locations : the small forest of Soeb Mountain $\left(L_{1}\right)$, the medium forest of AiniutLoeram $\left(L_{2}\right)$, and the large forest of Lapeom-Maubesi Mountain $\left(L_{3}\right)$. The data were collected using the quadrates method. Each transect is 0,52 ha and thirteen plots $(20 \times 20 \mathrm{~m})$ was established. The results show that the number of trees species in the large forest is the highest followed by the medium and the small forests $\left(L_{3}>L_{2}>L_{1}\right)$; The tree density in the large forest is the highest, followed by the small and the medium forests $\left(\mathbf{L}_{3}>\mathbf{L}_{1}>\mathbf{L}_{2}\right)$. However the highest tree basal area was recorded in the small forest, followed by the large and the medium forests $\left(L_{1}>L_{3}>L_{2}\right)$. The species of the highest importance value (IV) at three locations are Pterocarpus indicus Willd., Gossampinus malabarica (DC.) Merr., and Schleichera oleosa (Lour.) Oken.
\end{abstract}

Key Words : forest fragment, Timor Tengah Utara district, vegetation analysis.

Diterima: 5 Febuari 2003, disetujui: 10 Oktober 2003

\section{Pendahuluan}

Pulau Timor beriklim kering yang ditandai dengan tipe vegetasi savana, padang rumput, dan tipe hutan tropika musim (Banilodu and Saka, 1993). Menurut SBIPHK (1997), di Timor Tengah Utara (TTU) terdapat 126135 ha hutan tropika musim atau 47,25\% dari luas Wilayah TTU (266 970 ha). Kawasan hutan tersebut terdiri atas Hutan Lindung seluas 40970 ha $(32,48 \%)$, Hutan Produksi seluas 1556 ha $(1,19 \%)$, Hutan Produksi Terbatas seluas 68085 ha $(53,85 \%)$, Hutan Produksi yang dapat dikonversi seluas 13524 ha $(10,72 \%)$, dan Hutan Cagar Alam atau Suaka Margasatwa seluas 2000 ha $(1,53 \%)$.

Pada kawasan hutan tersebut terdapat Cendana (Santalum album L.) sebagai komoditi utama pendukung perekonomian Propinsi Nusa Tenggara Timur (NTT)
(Musakabe, 2000). Timor Tengah Utar merupakan salah satu dari tiga kabupate penghasil kayu Cendana tertinggi di Timor Selain Cendana terdapat juga jenis-jeni tumbuhan lain dan hewan-hewan liar yan, secara lokal berpotensi baik secara ekonom maupun ekologi (Hansitta, 2000). Dat mengenai keanekaragaman hayati di huta daerah tersebut sampai saat ini belum banya diketahui.

Konversi kawasan hutan menjadi laha pertanian semakin meningkat dari tahun $\mathrm{k}$ tahun, walaupun data luas hutan yang rusa belum diketahui dengan pasti, tetapi secar umum kondisi hutan di TTU mengalam kerusakan serius. Tindakan perusakan huta oleh masyarakat terjadi karena persepsi yan salah terhadap status hutan produksi terbatas Kawasan hutan pegunungan denga keanekaragaman biotik dan fungsi ekolog 
yang tinggi, telah di tetapkan sebagai hutan produksi terbatas seperti di kawasan hutan Ainiut-Loeram dan Oenbit. Sementara lahan dataran rendah yang meliputi sebagian besar wilayah, ditetapkan sebagai hutan lindung, misalnya lahan di hutan Eucalyptus platyphylla sebelah utara hutan Lapeom-Maubesi.

Penetapan status hutan yang kurang tepat akan berdampak pada peningkatan kegiatan penebangan hutan, sehingga menyebabkan berkurangnya luas kawasan hutan. Penurunan luas kawasan hutan akan mengancam keanekaragaman jenis tumbuhan (Caughley and Gunn, 1995; Anonim, 2001). Dampak ekologi dalam jangka panjang adalah terjadinya erosi ataubanjir yang semakin meningkat, penurunan produktivitas tanah, dan sumber air atau sumur akan kering.

Fragmen hutan dengan karakteristik vegetasi yang ada merupakan cerminan dari hasil konflik kepentingan hutan selama ini. Penelitian ini dilakukan dengan tujuan untuk mengkaji komposisi dan struktur vegetasi hutan-hutan tersebut baik di hutan besar atau luas maupun di hutan kecil. Diperkirakan fragmen hutan yang ada adalah hasil kegiatan fragmentasi oleh masyarakat sebelumnya. Diharapkan hasil penelitian ini bermanfaat sebagai bahan pertimbangan dalam penetapan status peruntukan hutan, perencanaan dan implementasi pengelolaan hutan di masa yang akan datang dan sebagai data dasar dalam penyuluhan dan kampanye konservasi hutan, tanah, dan air kepada masyarakat sekitar hutan.

\section{Metode Penelitian}

\section{Waktu dan lokasi penelitian}

Penelitian dilakukan pada bulan Oktober 2000 sampai Pebruari 2001 di tiga kawasan hutan TTU, yaitu hutan lindung gunung Soeb $(397,03$ ha), hutan produksi terbatas pegunungan Ainiut-Loeram (952,88 ha), dan hutan Lindung pegunungan Lapeom-Maubesi (4 310,62 ha).

Menurut O'Brien et al. (1997), luas hutan digolongkan atas tiga kategori yaitu Petak hutan kecil ( $<500$ ha), hutan sedang (500 - 1000 ha), dan petak hutan besar (> 1000 ha). Berdasarkan kategori tersebut, Kawasan hutan di TTU dapat digolongkan sebagai berikut: Hutan Lindung Gunung Soeb termasuk petak hutan kecil $\left(\mathrm{L}_{1}\right)$, hutan produksi terbatas pegunungan Ainiut-Loeram termasuk petak hutan sedang $\left(\mathrm{L}_{2}\right)$ dan hutan lindung pegunungan Lapeom-Maubesi termasuk petak hutan besar $\left(\mathrm{L}_{3}\right)$.

\section{Cara kerja}

Pengumpulan data dilakukan dengan menggunakan metode kuadrat (Soerianegara dan Indrawan, 1978; Arief 1994). Setiap fragmen hutan dibuat petak transek dari tepi hutan ke arah dalam memotong topografi hutan. Pada petak hutan kecil $\left(\mathrm{L}_{1}\right)$ dibuat satu petak transek; petak hutan sedang $\left(\mathrm{L}_{2}\right)$ dua petak transek, dan petak hutan besar $\left(\mathrm{L}_{3}\right)$ tiga petak transek, dengan luas setiap petak transek 0,52 ha (Vestal, 1949 dalam. Soerianegara dan Indrawan, 1978). Pada setiap petak transek dibuat 13 plot berukuran $20 \times 20 \mathrm{~m}$ dengan interval $20 \mathrm{~m}$.

Data dicatat dengan menghitung jumlah jenis dan jumlah individu per jenis. Data pohon dicatat dengan mengukur diameter batang setinggi dada (dbh) dan tinggi pohon. Voucher herbarium diidentifikasi di Herbarium Bogoriense - Bogor. Data sekunder studi meliputi data lokasi studi, sumber air atau sumur, dan data konversi tepi hutan diperoleh dengan metode dokumentasi dan wawancara.

\section{Analisis data}

Data dianalisis untuk membedakan komposisi dan struktur komunitas antar fragmen hutan. Indeks Nilai Penting jenis dianalisis dengan metode sebagai berikut:

$$
\begin{aligned}
& \operatorname{Kerapatan}(\mathrm{K})=\frac{\text { Jumlah individu }}{\text { Luas petak sampel }} \\
& \text { Kerapatan Relatif }(\mathrm{KR})=\frac{\begin{array}{c}
\text { Kerapatan suatu jenis } \\
\text { Kerapatan seluruh jenis }
\end{array}}{\text { Kon }} \\
& \text { Jumlah luas bidang dasar } \\
& \text { Dominasi }(\mathrm{D})=\text { Luas petak sampel }
\end{aligned}
$$




$$
\text { Dominasi Relatif }(\mathrm{DR})=\frac{\text { Dominansi suatu jenis }}{\text { Dominansi seluruh jenis }}
$$

Frekuensi $(\mathrm{F})=\frac{\text { Jumlah petak ditemukan suatu jenis }}{\text { Jumlah seluruh petak }}$
Frekuensi $(\mathrm{FR})=\frac{\text { Frekuensi suatu jenis }}{\text { Frekuensi seluruh jenis }} \times 100 \%$

Indeks Nilai Penting $(\mathrm{INP})=\mathrm{KR}+\mathrm{DR}+\mathrm{FR}$. (Cox, 1996)

Keanekaragaman jenis dihitung dengan menggunakan Indeks Shannon (Magurran, 1988):

$$
\mathrm{H}^{\prime}=-\sum_{i=1}^{S} p i \ln p i
$$

$$
\begin{aligned}
& \mathrm{H}^{\prime}=\text { indeks keanekaragaman Shannon } \\
& \mathrm{S}=\text { jumlah jenis } \\
& \mathrm{pi}=\text { proporsi antara individu jenis ke-i } \\
& \ln =\text { dengan jumlah total individu }(\mathrm{ni} / \mathrm{N}) .
\end{aligned}
$$

Ekuitabilitas dihitung dengan menggunakan Indeks Shannon :

$\mathrm{E}=\mathrm{H}^{\prime} / \ln \mathrm{S}$

$\mathrm{E}=$ indeks ekuitabilitas

$\mathrm{H}^{\prime}=$ indeks keanekaragaman Shannon

$\mathrm{S}=$ jumlah seluruh jenis. (Magurran, 1998).

Kesamaan tipe komunitas antar fragmen hutan ditentukan dengan menggunakan indeks Sørensen :

$$
\text { Indek Kesamaan }(I S)=\frac{2 \mathrm{~W}}{a+b} \times 100 \%
$$

$\mathrm{W}=$ jumlah nilai penting terkecil suatu jenis di kedua komunitas yang diperbandingkan.

$\mathrm{a}=$ jumlah nilai penting semua jenis di salah satu komunitas

$\mathrm{b}=$ jumlah nilai penting semua jenis di komunitas lain yang diperbandingkan.

(Mueller-Dombois and Ellenberg, 1974):

\section{Hasil dan Pembahasan}

\section{A. Komposisi jenis}

Pada ketiga lokasi sampel vegetasi huta (luas 3,12 ha) tercatat 57 jenis, 51 marga, da 32 suku tumbuhan berkayu. Dibandingka dengan hasil penelitian lain, maka kekayaa: jenis pohon di hutan TTU adalah $85 \%$ dar total jenis pohon (67 jenis) yang pernal terdapat di Timor (Anonim, 2000). Jenis-jeni tersebut relatif tidak berbeda dengan 58 jeni tumbuhan berkayu yang dijumpai di enan lokasi Cagar Alam (CA) Gunung Mutis yan, sebagian wilayahnya termasuk TTU (Banilodu 1998). Hal ini terjadi karena kedua lokas memiliki tipe hutan dan kondisi ekologi yan, relatif sama yakni sebagai hutan musima tropika pegunungan (tropical moonsu montain forest).

Jumlah jenis tertinggi terdapat di $\mathrm{L}$ diikuti $\mathrm{L}_{2}$, dan $\mathrm{L}_{1}\left(\mathrm{~L}_{3}>\mathrm{L}_{2}>\mathrm{L}_{1}\right)$ (Tabel 1) Indeks keanekaragaman Shannon ( $\left.\mathrm{H}^{\prime}\right)$ di $\mathrm{L}_{3}$ $\mathrm{L}_{2}>\mathrm{L}_{1}$. Perbandingan jumlah jenis dan nila $\mathrm{H}$ ' hasil studi ini menunjukkan bahwa di huta kecil mengandung jumlah jenis yang lebil rendah dibanding hutan besar. Jumlah jeni cenderung makin tinggi sejalan dengan maki meningkatnya luas hutan maupun jumlah ata luas petak sampling. Hasil perbandinga tersebut menunjukkan bahwa jumlah jenis d hutan kecil lebih rendah karena jumlah peta sampling lebih sedikit dan luas hutan lebi sempit dibandingkan dengan hutan besar.

Jika jumlah jenis pohon di tiap lokas diperbandingkan, maka di $\mathrm{L}_{1}$ tidak ditemuka 26 jenis (46\%) pohon; $\mathrm{L}_{2} 13$ jenis $(33 \%)$ da $\mathrm{L}_{3}$ tidak ditemukan 9 jenis ( $16 \%$ jenis) pohon Data ini menunjukkan bahwa telah terjad kepunahan lokal baik pada fragmen besa maupun pada fragmen kecil. Kepunahan jeni di fragmen hutan kecil lebih tingg dibandingkan hutan besar. Perbedaa kepunahan jenis antar fragmen besar dan keci merupakan indikasi pengaruh fragmentas hutan (Jati, 1998). Fragmentasi huta menyebabkan rendahnya jumlah jenis sebaga akibat dari banyak jenis yang hilang/punal secara lokal (Caughley and Gunn, 1995; Jat 1998). 
Tabel 1. Rata-rata jumlah jenis, marga, suku, indeks keanekaragaman, dan ekuitabilitas komunitas tumbuhan berkayu di ketiga lokasi hutan TTU yang diteliti

\begin{tabular}{lccc}
\hline \multirow{2}{*}{\multicolumn{1}{c}{ Parameter }} & \multicolumn{3}{c}{ Lokasi } \\
\cline { 2 - 4 } & Kecil $\left(\mathbf{L}_{\mathbf{1}}\right)$ & Sedang $\left(\mathbf{L}_{\mathbf{2}}\right)$ & Besar $\left(\mathbf{L}_{\mathbf{3}}\right)$ \\
\hline Jenis & 31 & 44 & 48 \\
Marga & 29 & 39 & 41 \\
Suku & 23 & 28 & 30 \\
Indeks keanekaragaman Shannon & 3.17 & 3.28 & 3.36 \\
Indeks Ekuitabilitas & 0.93 & 0.88 & 0.89 \\
\hline
\end{tabular}

Jumlah jenis yang rendah pada fragmen hutan kecil tidak hanya terjadi karena sempitnya lokasi dan rendahnya jumlah petak sampling, tetapi juga karena isolasi yang tinggi antar fragmen. Data menunjukkan bahwa jarak antara $\mathrm{L}_{1}, \mathrm{~L}_{2}$, dan $\mathrm{L}_{3}$ rata-rata $>5 \mathrm{~km}$. Menurut Hooff et al. (1996), jumlah jenis yang rendah pada hutan terfragmentasi disebabkan oleh tingginya isolasi dengan hutan asal. Hal ini disebabkan agen pemencar biji tidak mampu memencarkan biji.

Keanekaragaman jenis vegetasi yang rendah $\left(\mathrm{L}_{1}\right.$ dan $\left.\mathrm{L}_{2}\right)$ berpengaruh pada rendahnya keanekaragaman jenis burung sebagai agen pemencar biji. Hal ini merupakan konsekuensi logis dari jumlah jenis pohon yang rendah, struktur komunitas pohon yang rusak, punahnya pohon pakan, pohon tempat bersarang, dan pohon tempat berlindung (O’Brien et al., 1997; Jati, 1998).

Indeks Ekuitabilitas (E) $\mathrm{L}_{1}>\mathrm{L}_{3}>\mathrm{L}_{2}$ (Tabel 1) memperlihatkan indeks $E$ yang relatif tidak berbeda antara ketiga fragmen hutan. Hal tersebut terlihat dari banyaknya tingkat atau ranking kelimpahan yang terdiri atas lebih dari dua jenis pohon. Nilai indeks E yang demikian dikategorikan sebagai model distribusi kelimpahan jenis tongkat patah. Di setiap lokasi terdapat banyak jenis yang memiliki kelimpahan yang sama, sehingga membentuk petak-petak kelimpahan. Hal ini tampak dari kerapatan pohon tertinggi yang terdapat di $\mathrm{L}_{1}$, dimana kerapatan pohon tertinggi didominasi oleh tiga jenis yaitu Ziziphus timorensis DC., Mallotus philippensis (Lam.) Mull. Arg.., dan Randia densiflora (Wall.) Benth. dengan kerapatan masing-masing 25 individu/ha (Lampiran 1); sementara $\mathrm{L}_{2}$ dan $\mathrm{L}_{3}$ kerapatan tertinggi didominasi oleh satu jenis $\left(\mathrm{L}_{2}\right.$ didominasi Pterocarpus indicus Willd. dan $\mathrm{L}_{3}$ M. philippensis) (Lampiran 2 dan Lampiran 3).

Indeks $\mathrm{E}$ yang tinggi berarti tidak terdapat jenis yang lebih dominan dari jenisjenis lainnya (Banilodu and Saka, 1993). Ketiga jenis pohon yang dominan hutan kecil $\left(\mathrm{L}_{1}\right)$ mungkin salah satu akibat kegiatan fragmentasi hutan. Pemecahan hutan luas menjadi fragmen-fragmen kecil akan menyebabkan tumbuhnya jenis-jenis sekunder. Hal ini berkaitan dengan peningkatan jumlah daerah tepi hutan yang umumnya ditumbuhi jenis-jenis pioner (Primack et al., 1998; Anonim, 2001).

Indeks Kesamaan $\mathrm{L}_{1}-\mathrm{L}_{3}(70,45 \%)$ lebih tinggi dibanding IS $\mathrm{L}_{2}-\mathrm{L}_{3}(60,07 \%)$ dan IS $\mathrm{L}_{2}-\mathrm{L}_{1}(60,08)$. Jika jarak antara $\mathrm{L}_{3}-\mathrm{L}_{1}(5,2$ $\mathrm{km})$ dan jarak $\mathrm{L}_{3}-\mathrm{L}_{2}(6,5 \mathrm{~km})$, maka perbedaan IS antara lokasi tersebut terjadi karena perbedaan isolasi hutan (Jules, 1998; Primack et al., 1998). Fragmentasi menyebabkan IS antara hutan yang lebih terisolasi $\left(\mathrm{L}_{2}\right)$ dengan hutan asal $\left(\mathrm{L}_{3}\right)$ lebih rendah dibanding IS antara hutan yang kurang terisolasi $\left(\mathrm{L}_{1}\right)$ dengan hutan asal $\left(\mathrm{L}_{3}\right)$. Keadaan ini berkaitan dengan rendahnya kemampuan agen pemencar biji dari habitat luas ke habitat yang terisolasi tinggi atau sebaliknya (Hooff $e t$ al., 1996).

Ketiga lokasi studi memiliki IS jenis > $50 \%$. Hal ini menunjukkan bahwa ketiga fragmen hutan memiliki tipe komunitas hutan yang relatif sama (Kusumoantono, 1996). Kesamaan tipe komunitas menunjukkan bahwa ketiga fragmen hutan tersebut berasal dari hutan yang sama. Kesamaan tipe komunitas dan letak ketiga fragmen hutan yang 
berdekatan, SBIPHK (1997) mengelompokkan ketiga fragmen hutan tersebut menjadi satu kelompok hutan besar yang dinamai Bifemnase Sonmahole. Tipe komunitas yang sama antara ketiga fragmen hutan akan mendukung program reboisasi dengan jenisjenis potensial lokal yang sama.

\section{B. Struktur hutan}

Struktur hutan dapat diketahui dari distribusi kelas diameter pohon, tinggi pohon, distribusi jenis, dan asosiasi antar jenis. Distribusi kelas diameter pohon menggambarkan macam hutan ataupun keadaan lingkungannya. Distribusi pohon menurut diameter dan tinggi pohon dapat digunakan untuk melihat tingkat suksesi hutan (Soedjito, 1988).

\section{Kerapatan pohon}

$\mathrm{L}_{3}$ memiliki kerapatan pohon tertinggi $\left(\mathrm{L}_{3}>\mathrm{L}_{1}>\mathrm{L}_{2}\right)$. Perbedaan kerapatan tersebut disebabkan karena faktor-faktor lingkungan fisik yang ekstrim. $L_{2}$ memiliki kerapatan pohon terendah karena tingginya intensitas cahaya dan suhu serta rendahnya kelembaban di tepi hutan sebagai akibat konversi tepi hutan. Keadaan tersebut menyebabkan rendahnya perkecambahan biji dan kesintasan semai di tepi hutan (Duncan and Duncan, 2000; Anonim, 2001). Kerapatan pohon $\mathrm{L}_{1}>$ $\mathrm{L}_{2}$ karena $\mathrm{L}_{1}$ memiliki kelembaban udara lebih tinggi. Kerapatan pohon tertinggi di $\mathrm{L}_{3}$ karena semua faktor-faktor lingkungan berada dalam kondisi yang optimum (Huston, 1995).

\section{Basal area (BA) pohon}

Basal area pohon $\left(\mathrm{m}^{2} / \mathrm{ha}\right)$ tertinggi di $\mathrm{L}_{1}$, diikuti $\mathrm{L}_{3}$, dan $\mathrm{L}_{2}\left(\mathrm{~L}_{1}>\mathrm{L}_{3}>\mathrm{L}_{2}\right)$. Hal ini menunjukkan bahwa BA pohon tidak dipengaruhi ukuran fragmen hutan. Basal area pohon lebih dipengaruhi jenis-jenis yang tumbuh dan kondisi fisik lingkungan (Whitmore, 1986) dibandingkan dengan pengaruh ukuran hutan.

Pada $\mathrm{L}_{1}$, jenis yang memiliki BA tertinggi adalah Gossampinus malabarica (DC.) Merr. (107,61 $\left.\mathrm{m}^{2} / \mathrm{ha}\right)$ dengan dominansi relatif (DR) 23,82\% (lebih tinggi dibanding
DR jenis yang sama di $L_{2}$ dan $L_{3}$ ). Basal are pohon tertinggi di $\mathrm{L}_{1}$ tampak pad perbandingan jumlah pohon pada kela diameter batang 51-60 cm yang lebih banyal dibanding $\mathrm{L}_{3}$ dan $\mathrm{L}_{2}$. Di $\mathrm{L}_{3}$, BA poho didominasi oleh jenis sekunder, seperti $M$ philippensis. Pada $\mathrm{L}_{2}$, BA pohon didominasi $F$ indicus yang ukuran batangnya lebih kecil dar G. malabarica. Perbedaan DR jenis-jenis yan dominan antar lokasi menyebabkan berbedany iklim mikro habitat. Hal ini berpengaru terhadap perbedaan pembentukan BA pohon misalnya intensitas cahaya yang cukup tingg dapat membentuk diameter batang yang lebi tinggi (Whitmore, 1986).

Tingginya basal area pohon di L disebabkan karena faktor lingkungan fisik yan lebih mendukung, seperti tanah yang lebi subur dan persentase batu yang lebih rendal dibanding $\mathrm{L}_{2}$ dan $\mathrm{L}_{3}$. Menurut Kapos et a (1997), pada hutan-hutan terfragmentas mengandung banyak rumpang terutama pad tepi hutan yang berumur lebih muda. Denga demikian BA pohon yang lebih tinggi pada L diperkirakan karena jumlah petak sampel yan lebih sedikit dan umur tepi hutan yang lebi tua dibanding $\mathrm{L}_{2}$ dan $\mathrm{L}_{3}$. Pengaruh umur tep hutan terlihat pada BA pohon di $\mathrm{L}_{2}$ yang sanga rendah sebagai akibat konversi tepi hutan yan terjadi pada periode 1999 - 2001.

Untuk menggambarkan sukses komunitas pohon, struktur hutan dapat jug dilihat dari distribusi kelas diameter batang da kelas tinggi pohon (Soedjito, 1988). Menuru Kusumoantono (1996), distribusi kela diameter batang yang membentuk kurve huru "J" terbalik mencerminkan komunitas huta yang relatif tidak terganggu. Hasil studi in memperlihatkan distribusi kelas diameter yan kurang membentuk kurve huruf $\mathrm{J}$ terbali terutama pada kedua hutan kecil (Gambar 1) Hal ini membuktikan bahwa komunitas poho di ketiga hutan telah mengalami gangguan terutama pada kelas diameter pohon yang lebi besar dari $41 \mathrm{~cm}$. Kerusakan pohon yang cuku tinggi tampak pada $\mathrm{L}_{2}$ karena konversi tep hutan dan lokasi hutan yang lebih dekat denga pemukiman (O'Brien et al., 1997), misalny tepi hutan $\mathrm{L}_{2}$ yang dekat dengan kampun Nispukan dan Loeram. 


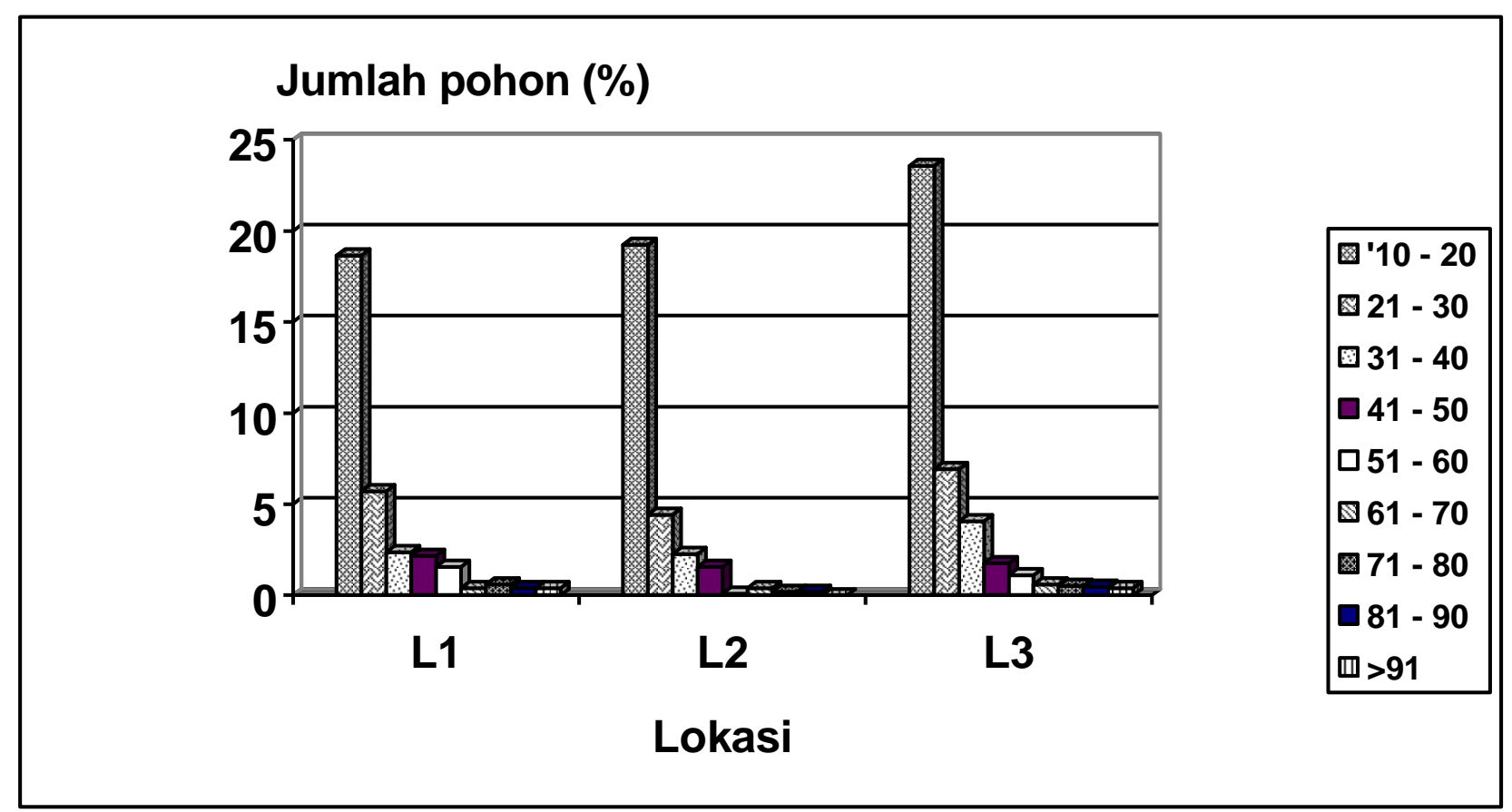

Gambar 1. Distribusi kelas diameter pohon ( $\mathrm{cm}$ ) di ketiga lokasi hutan Timor Tengah Utara Keterangan : $\mathrm{L}_{1}=$ Lokasi kecil; $\mathrm{L}_{2}=$ Lokasi sedang; $\mathrm{L}_{3}=$ Lokasi besar

Gambar 2 menunjukkan bahwa pada kedua hutan kecil terdapat proporsi jumlah pohon dari kelas tinggi pohon yang lebih rendah umumnya lebih banyak dibandingkan dengan proporsi jumlah pohon dari kelas tinggi pohon yang lebih tinggi. Di hutan besar proporsi jumlah pohon pada kelas tinggi pohon 30-45 m lebih tinggi dibanding kelas tinggi pohon 20-30 m. Kedua data tersebut menunjukkan bahwa regenerasi/suksesi hutan di kedua hutan kecil relatif lebih baik dibanding hutan besar. Di hutan besar telah terjadi degradasi jenis-jenis penting dan diganti oleh jenis-jenis sekunder yang kurang penting (Soedjito, 1988).

Jika data proporsi jumlah pohon berdasarkan kelas diameter dan tinggi pohon dibandingkan, dan dikaitkan dengan gangguan atau kerusakannya, maka diketahui bahwa ketiga lokasi hutan telah mengalami gangguan. Hal ini merupakan akibat dari fragmentasi hutan yang sejalan dengan meningkatnya jumlah tepi (Jules, 1998). Analisis data struktur vegetasi di atas menunjukkan bahwa struktur hutan di fragmen kecil lebih rendah dibandingkan dengan struktur hutan di fragmen besar, karena itu jika suksesi/regenerasi hutan di fragmen kecil lebih tinggi dibanding hutan besar, maka suksesi atau regenerasi yang cepat tersebut dipengaruhi kecepatan tumbuh jenisjenis yang toleran terhadap cahaya pada komunitas seral atau transisi (Banilodu and Saka, 1993).

Berdasarkan hasil analisis, komposisi jenis dan struktur vegetasi pohon di hutan kecil lebih rendah dibanding hutan besar. Kondisi vegetasi fragmen-fragmen hutan tersebut berkaitan dengan akibat fragmentasi hutan di TTU. Akibat fragmentasi hutan adalah selain terjadinya perubahan pola vegetasi, perubahan faktor abiotik yang drastis seperti tingginya cahaya dan suhu, serta rendahnya kelembaban udara (Caughley and Gunn, 1995). 


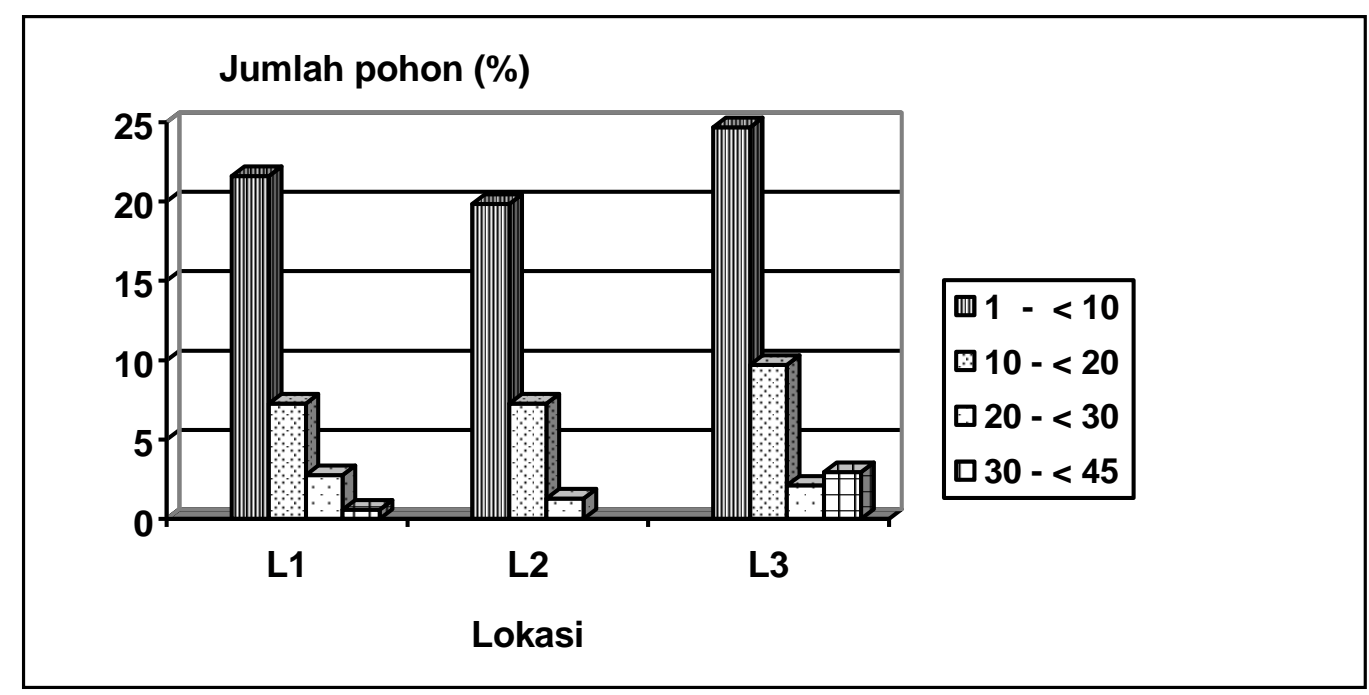

Gambar 2. Distribusi kelas tinggi pohon (m) di ketiga lokasi hutan Timor Tengah Utara. $\quad \mathrm{L}_{1}=$ Lokasi kecil; $\mathrm{L}_{2}=$ Lokasi sedang; $\mathrm{L}_{3}=$ Lokasi besar

Degradasi tersebut merupakan akibat dari tepi hutan sisa (Jules, 1998). Jumlah pohon yang rendah pada kelas tinggi 20-30 m diakibatkan karena eksploitasi yang tinggi pada pohonpohon berdiameter sedang (kelas tinggi 20-30 m) yang digunakan baik untuk rumah, pagar, maupun kayu bakar bagi penduduk Timor Dawan (Banilodu, 1998).

Diameter lokasi hutan $\mathrm{L}_{1} \pm 520 \mathrm{~m}$ (plot pengamatan terakhir terletak di puncak gunung) memungkinkan seluruh zona hutan dipengaruhi efek tepi. Efek tepi dapat meluas sampai $1000 \mathrm{~m}$ ke interior hutan (Primack et al. 1998; Anonim, 2001). Keadaan lingkungan hutan seperti ini tidak berbeda dengan kondisi lingkungan tepi hutan. Umumnya di zona hutan ini terdapat faktor-faktor fisik seperti cahaya, suhu, kelembaban, dan tekanan angin yang lebih ekstrim (Turton and Freiburger, 1997; Anonim, 2001). Kondisi ini akan menyebabkan persentase tutupan kanopi/struktur hutan yang lebih rendah yang erat kaitannya dengan rendahnya fungsi ekologi hutan (Kapos et al. 1997; Turton and Freiburger, 1997).

Menurut Kapos et al. (1997), pada zona hutan dengan pola struktur vegetasi rendah akan terjadi evapotranspirasi yang lebih tinggi; siklus air hujan lebih cepat; erosi tanah lebih tinggi; dan penyimpanan air tanah lebih sedikit. Hal ini berarti fragmentasi hutan yang makin meningkat di TTU akan mengakibatkan sumber-sumber/sumur air yang ada saat ini menjadi kering. Dalam jangka panjang pembangunan pertanian dan peternakan aka stagnant (O'Brien et al., 1997) bahkan aka menimbulkan fluktuasi iklim baik loka regional, maupun iklim global secara drasti (Kapos et al. 1997; Primack et al., 1998).

Berdasarkan akibat-akibat tersebut, mak pemahaman tentang akibat fragmentasi huta adalah penting untuk mengurangi penebanga tepi hutan. Selain itu pemahaman tentan keanekaragaman vegetasi di fragmen huta kecil saat ini tidak dapat diabaikan dalan Penetapan status dan Pengelolaan hutan yan berkelanjutan. Pemahaman secara utuh tentan status komposisi jenis dan struktur suatu huta diperlukan untuk perencanaan konservas hutan, tanah, dan air pada masa yang aka datang.

\section{Kesimpulan}

Berdasarkan hasil studi ini, mak diperoleh beberapa kesimpulan yaitu :

1. Komposisi jenis dan struktur vegetas tumbuhan berkayu di hutan besar $\left(\mathrm{L}_{3}\right.$ Lapeom-Maubesi) lebih tinggi dibandin hutan kecil dan sedang (Soeb dan Ainiut Loeram). Keadaan ini disebabkan karen fragmentasi hutan yang semakin meningka dari tahun ke tahun. 
2. Pada ketiga kawasan hutan ditemukan tiga jenis pohon yang berpotensi secara ekologi untuk dikembangkan karena memiliki INP tertinggi yaitu Pterocarpus indicus Willd., Gossampinus malabarica (DC.) Merr., dan Schleichera oleosa (Lour.) Oken. Di hutan besar komposisi jenis-jenis tersebut lebih tinggi dibanding hutan kecil, sedangkan struktur jenis di hutan kecil lebih tinggi dibanding hutan besar.

3. Perbedaan komposisi dan struktur vegetasi membuktikan bahwa akibat fragmentasi hutan di TTU telah mengubah komposisi dan struktur vegetasi hutan secara umum. Komposisi dan struktur vegetasi yang rendah berdampak negatif terhadap rendahnya fungsi hutan secara ekologi dan ekonomi. Hal ini ditunjukkan dengan rendahnya jumlah sumber air atau sumur; meningkatnya erosi; terganggunya kestabilan iklim lokal, regional, bahkan iklim global; maupun terhadap rendahnya pendapatan masyarakat dan daerah. Dalam jangka panjang, dampak tersebut mengarah kepada rendahnya laju pembangunan daerah TTU.

\section{Daftar Pustaka}

Anonim, 1997. SBIPHK (Sub Balai Inventarisasi dan Perpetaan Hutan Kupang). Keadaan Kawasan Hutan di wilayah Propinsi NTT menurut Pola Tata Guna Hutan Kesepakatan (TGHK), Kupang.

Anonim. 2001. Fragmentation - A Serious Threat to Ancient Forests - A Summary of the Current Scientific Knowledge - 2001. Greanpeace International Science Unit.

Arief, A.. 1994. Hutan: Hakikat pengaruhnya terhadap lingkungan. Yayasan Obor Indonesia, Jakarta: xii + 152 hlm.

Banilodu, L. and A.T. Saka. 1993. Analisis deskriptif hutan pulau Sumba. Kerjasama antara Birdlife International - Indonesia Programme dan Direktorat Jenderal Perlindungan Hutan dan Pelestarian Alam (PHPA) Departemen Kehutanan. Universitas Katolik Widya Mandira, Kupang: vi +76 hlm.
Banilodu, L.. 1998. Implikasi Etnobotani Kuantitatif dalam Kaitannya dengan Konservasi Gunung Mutis, Timor. Program Studi Biologi, Program Pascasarjana, Institut Pertanian Bogor, Bogor: $\mathrm{xx}+175 \mathrm{hlm}$.

Caughley, G. and A. Gunn. 1995. Conservation biology in theory and practice. Blackwell science, England: xii $+459 \mathrm{hlm}$.

Duncan, R. S. and V. E. Duncan. 2000. Forest succession and Distance from forest edge in an Afro-Tropical grassland. Biotropica 32(1): 33-41.

Hansitta, A. G. H. N.. 2000. Gerakan cinta hari esok Timor Tengah Utara memasuki abad ke - 21 . Kefamenanu: v $+240 \mathrm{hlm}$.

Hooff, V. V. J. A. K. A. M., J. Sayer, T. Boyle et al., 1996. The influence of forest fragmentation and habitat alteration on population of seed dispersers and herbivores in Sumatran rain forest. Research proposal. Center for International Forestry Research, Jakarta: 11 hlm.

Huston, M. A.. 1995. Biological Diversity, The coexistence of species on changing lanscapes. Cambridge University Press, Cambridge: $x v i i+681$ hlm.

Jati, A.. 1998. Kelimpahan dan distribusi jenis-jenis burung berdasarkan fragmentasi dan stratifikasi habitat hutan Cagar Alam Langgaliru Sumba. Program Studi Biologi, Program Pascasarjana, Institut Pertanian Bogor, Bogor: xvii + 206 hlm.

Jules, E. S.. 1998. Habitat fragmentation and demographic change for a common plant: Trillium in old-growth forest. Ecol. 79(5): 1645-1656.

Kapos, V., E. Wandelli, J. L. Camargo et al.,. 1997. Edge - Related Changes in Environment and Plant Respones Due to Forest Fragmentation in Central Amazonia. Dalam: Laurance, W. F. and R. O. Bierregaard. 1997. Tropical Forest Remnants, Ecology and Conservation of Fragmented Communities. The University of Chicago Press, Chicago: 33-44.

Kusumoantono. 1996. Komposisi dan struktur komunitas pohon di beberapa daerah tepi Taman Nasional Gunung Halimun dan pengaruhnya terhadap tumbuhan bawah. Universitas Indonesia - Fakultas Matematika dan Ilmu Pengetahuan Alam, Program Pascasarjana, Program Studi Biologi, Depok: xiii +63 hlm. 
Magurran, A. E.. 1988. Ecological Diversity and Its Measurment. Princeton University Press, Princeton: ix + 179 hlm.

Mueller, D, Dombois and H. Ellenberg. 1974. Aims and Methods of Vegetation Ecology. John Wiley \& Sons, New York: xix + 547 hlm.

Musakabe, H.. 2000. Peluang dan Kendala Cendana dalam Perekonomian Propinsi NTT. Dalam: Kumpulan Makalah Seminar Nasional Kajian terhadap Tanaman Cendana (S. album L.) Sebagai Komoditi Utama Perekonomian NTT Menuju Otonomisasi 2000. Pemerintah Daerah Tingkat I NTT - LIPI. Jakarta: 12-17.

O'Brien, T. G., M. F. Kinnaird, P. Jepson et al., 1997. Evaluasi kualitas habitat Rangkong Sumba dan Kakatua Cempaka di Sumba, Nusa Tenggara Timur, dengan rekomendasi untuk konservasi habitat hutan. PHPA/Wildlife Conservation Society Indonesia Program Memorandum teknis 2 bekerjasama dengan Birdlife International Indonesia Programme, Bogor: $8 \mathrm{hlm}$.

Primack, R. B., J. Supriatna, M. Idrawan et al., 1998. Biologi konservasi. Yayasan obor Indonesia, Jakarta: vi + 345 hlm.
Soedjito, H.. 1988. Dinamika komunitas tumbuha dan perladangan berpindah di Long Segar Kalimantan timur- Dampak kegiatan manusi terhadap komunitas tumbuhan di Kalimanta timur. Dalam: Kumpulan makalah semina dan penelitian, MAB Indonesia: $13 \mathrm{hlm}$.

Soerianegara, I. dan A. Indrawan. 1978. Ekolog hutan Indonesia. Departemen Manajeme hutan, Fakultas Kehutanan Institut Pertania Bogor, Bogor: $80 \mathrm{hlm}$.

Turton, S.T.and H. J. Freiburger. 1997. Edge an Aspect Effets on the Microclimate of a Sma Forest Remnant on the Atherton Tablelanc Northeastern Australia. Dalam: Laurance, W F. and R. O. Bierregaard. 1997. Tropicc Forest Remnants, Ecology and Conservatio of Fragmented Communities. The Universit of Chicago Press, Chicago: 45-54.

Whitmore, T. C.. 1986. Tropical rain forests of th far east. Oxford University press, Witney $\mathrm{xvi}+352 \mathrm{hlm}$.

Lampiran 1. Indeks Nilai Penting (INP) Tumbuhan Berkayu di L (Hutan Gunung Soeb)

\begin{tabular}{llccccc}
\hline No. & \multicolumn{1}{c}{ Jenis } & Ind./ha & KR & DR & FR & INP \\
\hline 1. & Gossampinus malabarica (DC.) Merr. & 12 & 3.66 & 23.82 & 3.41 & 30.88 \\
2. & Mallotus philippensis Karst. & 25 & 7.93 & 8.03 & 4.55 & 20.50 \\
3. & Firmiana cf. Malayana Kosterm. & 17 & 5.49 & 9.63 & 4.55 & 19.67 \\
4. & Ziziphus timorensis DC. & 25 & 7.93 & 3.51 & 7.95 & 19.39 \\
5. & Litsea glutinosa (Lour.) C.B. Rob. & 21 & 6.71 & 5.95 & 5.68 & 18.34 \\
6. & Schleichera oleosa (Lour.) Oken & 10 & 3.05 & 9.88 & 4.55 & 17.47 \\
7. & Pterocarpus indicus Willd. & 13 & 4.27 & 7.41 & 4.55 & 16.22 \\
8. & Randia densiflora (Wall.) Benth. & 25 & 7.93 & 2.47 & 4.55 & 14.94 \\
9. & Cordia subcordata Lamk. & 17 & 5.49 & 2.08 & 5.68 & 13.25 \\
10. & Acacia villosa (Sw.) Willd. & 15 & 4.88 & 1.19 & 4.55 & 10.61 \\
11. & Wrightia javanica DC. & 13 & 4.27 & 1.39 & 4.55 & 10.20 \\
12. & Bridelia insulana Hance & 12 & 3.66 & 0.84 & 5.68 & 10.18 \\
13. & Celtis philippensis Blanco & 15 & 4.88 & 1.32 & 3.41 & 9.61 \\
14. & Ixora sp. & 17 & 5.49 & 0.27 & 3.41 & 9.17 \\
15. & Vitex pinnata L. & 8 & 2.44 & 3.05 & 3.41 & 8.90 \\
16. & Cassia javanica L. & 10 & 3.05 & 1.45 & 3.41 & 7.91 \\
17. & Tamarindus indica L. & 6 & 1.83 & 3.62 & 2.27 & 7.73 \\
18. & Garuga floribunda Decne & 4 & 1.22 & 3.44 & 2.27 & 6.93 \\
19. & Ficus benjamina L. & 2 & 0.61 & 5.12 & 1.14 & 6.87 \\
20. & Tectona grandis L.f. & 8 & 2.44 & 0.92 & 3.41 & 6.77 \\
21. & Psidium guajava L. & 12 & 3.66 & 0.59 & 2.27 & 6.52 \\
22. & Cordia dichotoma Forst.f. & 4 & 1.22 & 1.26 & 2.27 & 4.75 \\
23. & Terminalia microcarpa Decne & 6 & 1.83 & 0.29 & 2.27 & 4.40 \\
24. & Pterygota sp. & 4 & 1.22 & 0.60 & 2.27 & 4.09 \\
25. & Albizia lebbeck (L.) Benth. & 2 & 0.61 & 0.86 & 1.14 & 2.61 \\
\hline
\end{tabular}




\begin{tabular}{llccccc}
\hline No. & \multicolumn{1}{c}{ Jenis } & Ind./ha & KR & DR & FR & INP \\
\hline 26. & Barringtonia acutangula (L.) Gaertner & 4 & 1.22 & 0.16 & 1.14 & 2.52 \\
27. & Dendrochnide sp. & 2 & 0.61 & 0.32 & 1.14 & 2.07 \\
28. & Casearia cf. Hexagona Denn. & 2 & 0.61 & 0.20 & 1.14 & 1.95 \\
29. & Annona squamosa L. & 2 & 0.61 & 0.13 & 1.14 & 1.88 \\
30. & Euonymus cochinchinensis Pierre & 2 & 0.61 & 0.11 & 1.14 & 1.86 \\
31. & Acacia oraria F.v.M. & 2 & 0.61 & 0.09 & 1.14 & 1.84 \\
\hline \multicolumn{1}{c}{ Jumlah } & $\mathbf{3 1 5}$ & $\mathbf{1 0 0}$ & $\mathbf{1 0 0}$ & $\mathbf{1 0 0}$ & $\mathbf{3 0 0}$ \\
\hline
\end{tabular}

Lampiran 2. Indeks Nilai Penting (INP) Tumbuhan Berkayu di L2 (Hutan Pegunungan Ainiut-Loeram)

\begin{tabular}{|c|c|c|c|c|c|c|}
\hline No. & Jenis & Ind./ha & $\mathbf{K R}$ & DR & FR & INP \\
\hline 1. & Pterocarpus indicus Willd. & 36 & 12.80 & 13.86 & 6.94 & 33.60 \\
\hline 2. & Schleichera oleosa (Lour.) Oken & 30 & 10.73 & 8.35 & 9.25 & 28.33 \\
\hline 3. & Tamarindus indica $\mathrm{L}$. & 20 & 7.27 & 7.54 & 7.51 & 22.32 \\
\hline 4. & Grewia koordersii Burret & 22 & 7.96 & 7.33 & 6.94 & 22.22 \\
\hline 5. & Dendrochnide sp. & 9 & 3.11 & 15.24 & 2.89 & 21.25 \\
\hline 6. & Garuga floribunda Decne & 7 & 2.42 & 6.81 & 3.47 & 12.71 \\
\hline 7. & Gossampinus malabarica (DC.) Merr. & 8 & 2.77 & 5.33 & 4.05 & 12.15 \\
\hline 8. & Albizia saponaria (Lour.) Blume ex Miq. & 13 & 4.50 & 2.15 & 3.47 & 10.11 \\
\hline 9. & Acacia villosa (Sw.) Willd. & 14 & 5.19 & 1.59 & 2.89 & 9.67 \\
\hline 10. & Ficus benjamina $\mathrm{L}$. & 3 & 1.04 & 6.28 & 1.73 & 9.05 \\
\hline 11. & Mallotus philippensis (Lam.) Mull. Arg. & 11 & 3.81 & 1.20 & 3.47 & 8.47 \\
\hline 12. & Vitex pinnata $\mathrm{L}$ & 8 & 2.77 & 2.36 & 2.89 & 8.01 \\
\hline 13. & Wrightia javanica DC. & 9 & 3.11 & 2.22 & 2.31 & 7.65 \\
\hline 14. & Acacia leucophloea (Roxb.) Willd. & 6 & 2.08 & 1.99 & 2.89 & 6.95 \\
\hline 15. & Macaranga tanarius Mull. Arg. & 8 & 2.77 & 1.23 & 2.89 & 6.89 \\
\hline 16. & Celtis philippensis Blanco & 7 & 2.42 & 0.98 & 3.47 & 6.87 \\
\hline 17. & Cordia subcordata Lamk. & 6 & 2.08 & 1.08 & 2.89 & 6.05 \\
\hline 18. & Zizyphus timorensis DC. & 5 & 1.73 & 1.05 & 2.89 & 5.67 \\
\hline 19. & Strychnos muricata Kosterm. & 6 & 2.08 & 0.85 & 2.31 & 5.24 \\
\hline 20. & Randia densiflora (Wall.) Benth. & 5 & 1.73 & 1.02 & 2.31 & 5.06 \\
\hline 21. & Zizyphus jujuba Mill. & 4 & 1.38 & 0.94 & 2.31 & 4.63 \\
\hline 22. & Cordia dichotoma Forst.f. & 5 & 1.73 & 0.37 & 2.31 & 4.42 \\
\hline 23. & Lannea coromandelica (Houtt.) Merr. & 4 & 1.38 & 1.60 & 0.58 & 3.56 \\
\hline 24. & Pipturus argenteus (Forst.f.) Wedd. & 3 & 1.04 & 0.23 & 1.73 & 3.00 \\
\hline 25. & Terminalia microcarpa Decne & 4 & 1.38 & 0.43 & 1.16 & 2.97 \\
\hline 26. & Annona squamosa $\mathrm{L}$. & 3 & 1.04 & 0.49 & 1.16 & 2.69 \\
\hline 27. & Albizia lebbeck (L.) Benth. & 2 & 0.69 & 0.80 & 1.16 & 2.65 \\
\hline 28. & Zizyphus nummularia & 3 & 1.04 & 0.80 & 0.58 & 2.41 \\
\hline 29. & Bauhinia purpurea $\mathrm{L}$. & 3 & 1.04 & 0.78 & 0.58 & 2.40 \\
\hline 30. & Acacia oraria F.v.M. & 1 & 0.35 & 1.32 & 0.58 & 2.25 \\
\hline 31. & Pterygota $\mathrm{sp}$ & 1 & 0.35 & 1.32 & 0.58 & 2.25 \\
\hline 32. & Litsea glutinosa (Lour.) C.B. Rob. & 2 & 0.69 & 0.23 & 1.16 & 2.08 \\
\hline 33. & Bauhinia malabarica Roxb. & 2 & 0.69 & 0.22 & 1.16 & 2.07 \\
\hline 34. & Melia azedarach $\mathrm{L}$. & 2 & 0.69 & 0.19 & 1.16 & 2.04 \\
\hline 35. & Scolopia macrophylla (W.and A.) Clos. & 2 & 0.69 & 0.12 & 1.16 & 1.97 \\
\hline 36. & Leucaena glauca (Willd.) Benth. & 2 & 0.69 & 0.22 & 0.58 & 1.49 \\
\hline 37. & Firmiana cf. Malayana Kosterm. & 1 & 0.35 & 0.45 & 0.58 & 1.37 \\
\hline 38. & Bombax ceiba $\mathrm{L}$ & 1 & 0.35 & 0.29 & 0.58 & 1.21 \\
\hline 39. & Diospyros montana Roxb. & 1 & 0.35 & 0.25 & 0.58 & 1.18 \\
\hline
\end{tabular}


Poleng dan Witono

\begin{tabular}{|c|c|c|c|c|c|c|}
\hline No. & Jenis & Ind./ha & KR & DR & FR & INP \\
\hline 40. & $\begin{array}{l}\text { Clausena excavata (Burm.f.) Hook. and } \\
\text { Thomson }\end{array}$ & 1 & 0.35 & 0.18 & 0.58 & 1.11 \\
\hline 41. & Bridelia insulana Hance & 1 & 0.35 & 0.10 & 0.58 & 1.02 \\
\hline 42. & Cassia javanica $\mathrm{L}$. & 1 & 0.35 & 0.08 & 0.58 & 1.01 \\
\hline 43. & Euonymus cochinchinensis Pierre & 1 & 0.35 & 0.06 & 0.58 & 0.99 \\
\hline 44. & Alstonia villosa Blume & 1 & 0.35 & 0.05 & 0.58 & 0.98 \\
\hline & Jumlah & 278 & 100 & 100 & 100 & 300 \\
\hline
\end{tabular}

Lampiran 3. Indeks Nilai Penting (INP) Tumbuhan Berkayu di L $\mathrm{L}_{3}$ (Hutan Pegunungan LapeomMaubesi)

\begin{tabular}{|c|c|c|c|c|c|c|}
\hline No. & Jenis & Ind./ha & KR & DR & FR & INP \\
\hline 1. & Mallotus philippensis (Lam.) Mull. Arg. & 51 & 13.29 & 5.90 & 6.36 & 25.55 \\
\hline 2. & Garuga floribunda Decne & 17 & 4.49 & 11.32 & 6.36 & 22.17 \\
\hline 3. & Litsea glutinosa (Lour.) C.B. Rob. & 39 & 10.13 & 4.06 & 4.59 & 18.79 \\
\hline 4. & Mangifera laurina Blume & 13 & 3.49 & 12.95 & 0.71 & 17.15 \\
\hline 5. & Pterocarpus indicus Willd. & 17 & 4.49 & 8.55 & 3.89 & 16.92 \\
\hline 6. & Ficus benjamina $\mathrm{L}$. & 9 & 2.33 & 10.03 & 2.12 & 14.48 \\
\hline 7. & Pterygota sp. & 24 & 6.15 & 3.79 & 3.89 & 13.83 \\
\hline 8. & Vitex pinnata $\mathrm{L}$ & 17 & 4.32 & 3.64 & 4.59 & 12.55 \\
\hline 9. & Ziziphus timorensis DC. & 15 & 3.82 & 1.68 & 5.30 & 10.80 \\
\hline 10. & Acacia villosa (Sw.) Willd. & 15 & 3.82 & 1.16 & 4.95 & 9.93 \\
\hline 11. & Albizia lebbeck (L.) Benth. & 4 & 1.00 & 6.78 & 1.06 & 8.84 \\
\hline 12. & Tamarindus indica $\mathrm{L}$. & 15 & 3.99 & 0.48 & 4.24 & 8.71 \\
\hline 13. & Bridelia insulana Hance & 10 & 2.49 & 1.54 & 4.59 & 8.63 \\
\hline 14. & Gossampinus malabarica (DC.) Merr. & 10 & 2.66 & 1.16 & 4.59 & 8.42 \\
\hline 15. & Schleichera oleosa (Lour.) Oken & 8 & 1.99 & 2.46 & 2.83 & 7.28 \\
\hline 16. & Acacia leocophloea (Roxb.) Willd. & 8 & 2.16 & 2.63 & 2.12 & 6.91 \\
\hline 17. & Celtis philippensis Blanco & 8 & 2.16 & 1.25 & 2.83 & 6.24 \\
\hline 18. & Cordia subcordata Lamk. & 8 & 1.99 & 0.75 & 3.18 & 5.93 \\
\hline 19. & Tectona grandis L.f. & 9 & 2.33 & 2.93 & 0.35 & 5.60 \\
\hline 20. & Ziziphus sp. & 9 & 2.33 & 0.22 & 2.83 & 5.37 \\
\hline 21. & Albizia saponaria (Lour.) Blume ex Miq. & 8 & 1.99 & 0.62 & 2.47 & 5.09 \\
\hline 22. & $\begin{array}{l}\text { Clausena excavata (Burm.f.) Hook. and } \\
\text { Thomson }\end{array}$ & 6 & 1.50 & 0.96 & 2.47 & 4.93 \\
\hline 23. & Cordia dichotoma Forst.f. & 5 & 1.33 & 0.96 & 2.47 & 4.76 \\
\hline 24. & Aleurites mollucana (L.) Willd. & 4 & 1.16 & 1.10 & 2.12 & 4.38 \\
\hline 25. & Strychnos muricata Kosterm. & 3 & 0.83 & 1.63 & 1.77 & 4.23 \\
\hline 26. & Zizyphus jujuba Mill. & 2 & 0.50 & 3.21 & 0.35 & 4.07 \\
\hline 27. & Eucalyptus alba Reinw. Ex Blume & 8 & 1.99 & 1.13 & 0.71 & 3.83 \\
\hline 28. & Casearia cf. Hexagona Denn. & 4 & 1.00 & 0.63 & 2.12 & 3.74 \\
\hline 29. & Firmiana cf. malayana Kosterm. & 4 & 1.00 & 0.73 & 1.41 & 3.14 \\
\hline 30. & Cassia javanica L. & 4 & 1.00 & 0.82 & 1.06 & 2.88 \\
\hline 31. & Lannea coromandelica (Houtt.) Merr. & 3 & 0.83 & 0.54 & 1.41 & 2.79 \\
\hline 32. & Melia azedarach $\mathrm{L}$. & 5 & 1.33 & 0.89 & 0.35 & 2.57 \\
\hline 33. & Macaranga tanarius Mull. Arg. & 3 & 0.66 & 0.55 & 1.06 & 2.28 \\
\hline 34. & Exocarpus latifolia $\mathrm{R} . \mathrm{Br}$. & 3 & 0.66 & 0.11 & 1.41 & 2.19 \\
\hline 35. & Pittosporum mollucanum (Lam.) Miq. & 3 & 0.83 & 0.25 & 1.06 & 2.14 \\
\hline 36. & Bauhinia purpurea $\mathrm{L}$. & 3 & 0.66 & 0.32 & 1.06 & 2.04 \\
\hline 37. & Dendrochnide sp. & 2 & 0.50 & 0.94 & 0.35 & 1.80 \\
\hline 38. & Annona squamosa L. & 2 & 0.50 & 0.09 & 0.71 & 1.30 \\
\hline 39. & Diospyros montana Roxb. & 2 & 0.33 & 0.07 & 0.71 & 1.11 \\
\hline 40. & Randia densiflora (Wall.) Benth. & 2 & 0.33 & 0.06 & 0.71 & 1.10 \\
\hline
\end{tabular}


Analisis Vegetasi Hutan di Timor Tengah Utara

\begin{tabular}{llccccc}
\hline No. & \multicolumn{1}{c}{ Jenis } & Ind./ha & KR & DR & FR & INP \\
\hline 41. & Grewia koordersii Burret & 1 & 0.17 & 0.30 & 0.35 & 0.81 \\
42. & Leucaena glauca (Willd.) Benth. & 1 & 0.17 & 0.25 & 0.35 & 0.77 \\
43. & Acacia oraria F.v.M. & 1 & 0.33 & 0.08 & 0.35 & 0.77 \\
44. & Psidium guajava L. & 1 & 0.33 & 0.08 & 0.35 & 0.77 \\
45. & Alstonia scholaris (L.) R.Br. & 1 & 0.17 & 0.14 & 0.35 & 0.66 \\
46. & Alstonia villosa Blume & 1 & 0.17 & 0.13 & 0.35 & 0.65 \\
47. & Bauhinia malabarica Roxb. & 1 & 0.17 & 0.04 & 0.35 & 0.56 \\
48. & Delonix regia (Bojer ex Hook.) Rafin. & 1 & 0.17 & 0.04 & 0.35 & 0.56 \\
\hline \multicolumn{2}{r}{ Jumlah } & $\mathbf{3 8 6}$ & $\mathbf{1 0 0}$ & $\mathbf{1 0 0}$ & $\mathbf{1 0 0}$ & $\mathbf{3 0 0}$ \\
\hline
\end{tabular}

